General. All manipulations were carried out under a nitrogen atmosphere. Nitrogen gas was dried by passage through $\mathrm{P}_{2} \mathrm{O}_{5}$. NMR spectra were recorded on a JEOL JNM-LA400 spectrometer (400 $\mathrm{MHz}$ for ${ }^{1} \mathrm{H}, 100 \mathrm{MHz}$ for $\left.{ }^{13} \mathrm{C}\right)$, or JEOL JNM-LA500 spectrometer $\left(500 \mathrm{MHz}\right.$ for $\left.{ }^{1} \mathrm{H}\right)$. All NMR spectra were recorded in chloroform-d at $25{ }^{\circ} \mathrm{C}$. $\mathrm{HPLC}$ analysis was performed on a JASCO PU-1580 liquid chromatograph system. Optical rotations were measured on a JASCO P-1020 polarimeter. The agitation of the reaction mixture containing resin-supported catalysts was performed on a wrist-action shaker (Burrel Scientific, Inc.) and a Peti-Syzer (Shimadzu Scientific Research Inc).

Asymmetric allylic amination in water:

(S)- $N, N$-Dibenzyl(cyclohexen-2-yl)amine 7a: A typical procedure for the reaction of cyclohexenyl carbonate $\mathbf{2}$ with dibenzylamine (6a) in the presence of catalyst 1-Pd to give $(S)-N, N$-dibenzyl-(cyclohexen-2yl)amine (7a) is as follows: A mixture of cyclohexenyl carbonate 2 (39 $\mathrm{mg}, \quad 0.25 \mathrm{mmol})$, dibenzylamine $(247 \mathrm{mg}, 1.25 \mathrm{mmol})$, 1-Pd (68 $\mathrm{mg}, 0.020 \mathrm{mmol})$, and $\mathrm{H}_{2} \mathrm{O}(1.25 \mathrm{~mL})$ was agitated at $25^{\circ} \mathrm{C}$ for $24 \mathrm{~h}$. The reaction mixture was filtered and the resin beads were rinsed three times with THF ( $3 \times 2 \mathrm{~mL})$. The combined filtrate and washings were extracted with ethyl acetate and the extract was dried over $\mathrm{Na}_{2} \mathrm{SO}_{4}$. After removal of the solvent, the residual oil was chromatographed on silica gel to give 7a (63 mg): $90 \%$ yield; $[\alpha]_{\mathrm{D}}^{25}-14.1$ ( $c 0.85$, dichloromethane); ${ }^{1} \mathrm{H}$ NMR (chloroform- $d$ ) $\delta 1.50(\mathrm{~m}, 2 \mathrm{H}), 1.78(\mathrm{~m}, 1 \mathrm{H}), 1.94(\mathrm{~m}, 3 \mathrm{H}), 3.34$ (br s, $1 \mathrm{H})$, 3.54 (d, $J=13.9 \mathrm{~Hz}, 2 \mathrm{H}), 3.73$ (d, $J=14.2 \mathrm{~Hz}, 2 \mathrm{H}), 5.74$ (br d, J = 10.3 $\mathrm{Hz}, 1 \mathrm{H}), 5.81(\mathrm{brd}, J=11.7 \mathrm{~Hz}, 1 \mathrm{H}), 7.19(\mathrm{t}, J=7.3 \mathrm{~Hz}, 2 \mathrm{H}), 7.28(\mathrm{t}, J=$ $7.3 \mathrm{~Hz}, 4 \mathrm{H}), 7.39$ (d, $J=8.1 \mathrm{~Hz}, 4 \mathrm{H}) .{ }^{13} \mathrm{C}$ NMR (chloroform-d) $\delta 21.9$, 23.2, 25.4, 53.8, 54.5, 126.5, 128.0, 128.4, 129.9, 13.7, 140.7. Anal Calcd for $\mathrm{C}_{20} \mathrm{H}_{23} \mathrm{~N}$ : C, 86.59; H, 8.36; N, 5.05. Found: C, 86.40; H, 8.44; N, 4.84. The enantiomeric excess was determined by HPLC analysis using a chiral stationary phase column (DAICEL OJ: eluent, n-hexane/2propanol=300/1; flow rate $0.5 \mathrm{~mL} / \mathrm{min}$ ) to be $94 \%$ ee. A typical HPLC chart is given below (Chart I). The absolute configuration was determined by HPLC analysis compared with authentic $(S)$-7a prepared from $(S)$ benzyl(cyclohexen-2-yl)amine (Chart II).

(S)- $\boldsymbol{N}$-Benzyl- $\boldsymbol{N}$-p-methoxybenzyl(cyclohexen-2-yl)amine $\mathbf{7 b}: \quad 77 \%$ yield; $[\alpha]_{\mathrm{D}}{ }^{25}-15.4$ (c 1.0, dichloromethane); ${ }^{1} \mathrm{H}$ NMR (chloroform- $d$ ) $\delta$ $1.48(\mathrm{~m}, 2 \mathrm{H}), 1.71-2.05(\mathrm{~m}, 4 \mathrm{H}), 3.32(\mathrm{br} \mathrm{s}, 1 \mathrm{H}), 3.45(\mathrm{~d}, J=13.7 \mathrm{~Hz}, 1 \mathrm{H})$, $3.51(\mathrm{~d}, J=14.2 \mathrm{~Hz}, 1 \mathrm{H}), 3.65(\mathrm{~d}, J=13.7 \mathrm{~Hz}, 1 \mathrm{H}), 3.71(\mathrm{~d}, J=14.2 \mathrm{~Hz}$, $1 \mathrm{H}), 3.77$ (s, 3H), 5.72 (br d, $J=10.0 \mathrm{~Hz}, 1 \mathrm{H}), 5.79$ (br s, 1H), 6.83 (d, $J$ $=8.3 \mathrm{~Hz}, 2 \mathrm{H}), 7.17-7.30(\mathrm{~m}, 3 \mathrm{H}), 7.29(\mathrm{~d}, J=8.3 \mathrm{~Hz}, 2 \mathrm{H}), 7.37(\mathrm{~d}, J=$ $7.3 \mathrm{~Hz}, 2 \mathrm{H}$ ). ${ }^{13} \mathrm{C}$ NMR (chloroform- $d$ ) $\delta 21.9,23.2,25.4,53.2,53.7,54.4$, 55.2, 113.5, 126.5, 128.0, 128.4, 129.4, 129.8, 130.9, 132.7, 140.9, 158.3. Anal Calcd for $\mathrm{C} 21 \mathrm{H} 25 \mathrm{NO}$ : C, 82.03; H, 8.20; N, 4.56. Found: C, $81.95 ; \mathrm{H}, 8.37 ; \mathrm{N}, 4.54$. The enantiomeric excess was determined by HPLC analysis using a chiral stationary phase column (DAICEL OD-H: eluent, $\mathrm{n}$-hexane $/ 2$-propanol=1000/1; flow rate $0.5 \mathrm{~mL} / \mathrm{min}$ ) to be $92 \%$ ee.
A typical HPLC chart is given below (Chart I). The absolute configuration was determined to be $S$ by comparison of the specific rotation and HPLC order after conversion to $\mathbf{7 a}$ (Chart II).

(S)-N,N-Bis-p-methoxybenzyl(cyclohexen-2-yl)amine $7 \mathrm{c}: \quad 75 \%$ yield; $[\alpha]_{\mathrm{D}}{ }^{25}-18.1$ (c 1.3, dichloromethane); ${ }^{1} \mathrm{H}$ NMR (chloroform- $d$ ) $\delta$ 1.40-2.00 (m, 6H), $3.31($ br s, $1 \mathrm{H}), 3.44$ (d, $J=13.7 \mathrm{~Hz}, 2 \mathrm{H}), 3.64$ (d, $J=$ $13.7 \mathrm{~Hz}, 2 \mathrm{H}), 3.78(\mathrm{~s}, 6 \mathrm{H}), 5.70(\mathrm{br} \mathrm{d}, J=10.0 \mathrm{~Hz}, 1 \mathrm{H}), 5.80($ br d, $J=$ $10.3 \mathrm{~Hz}, 1 \mathrm{H}), 6.83(\mathrm{~d}, J=8.3 \mathrm{~Hz}, 4 \mathrm{H}), 7.28(\mathrm{~d}, J=8.3 \mathrm{~Hz}, 4 \mathrm{H}) .{ }^{13} \mathrm{C}$ NMR (chloroform- $d$ ) $\delta 22.0,23.2,25.4,53.0,54.2,55.3,113.4,129.4$, 129.4, 130.9, 132.9, 158.3. Anal Calcd for $\mathrm{C}_{22} \mathrm{H}_{27} \mathrm{NO}_{2}: \mathrm{C}, 78.29 ; \mathrm{H}$, 8.07; N, 4.15. Found: C, 78.40; H, 8.44; N, 4.41. The enantiomeric excess was determined by HPLC analysis using a chiral stationary phase column (DAICEL OD-H: eluent, n-hexane/2-propanol=1000/1; flow rate $0.5 \mathrm{~mL} / \mathrm{min}$ ) to be $90 \%$ ee. A HPLC chart is given below (Chart I). The absolute configuration of 7c was determined to be $S$ by comparison of the specific rotation and HPLC order after conversion to 7a (Chart II).

Oxidative cleavage of $N$-methoxybenzyl groups: General procedure. To a solution of $\mathbf{N}$-methoxybenzylamine $(0.1 \mathrm{mmol})$ in 1.1 $\mathrm{mL}$ of $\mathrm{CH}_{2} \mathrm{Cl}_{2}-\mathrm{H}_{2} \mathrm{O}$ (10:1) was added cerium ammonium nitrate $(274 \mathrm{mg}$, $0.5 \mathrm{mmol}$ ) at room temperature. The reaction mixture was stirred for $1 \mathrm{hr}$ and then quenched with $1 \mathrm{~N}-\mathrm{NaOHaq}$. The mixture was extracted with diethyl ether and dried over $\mathrm{Na}_{2} \mathrm{SO}_{4}$. Upon removal of the solvent, the resulting crude residue was chromatographed on alumina to give cycloalkenylamine in $60-90 \%$ yield.

The enantiomeric purity of the resulting amines were determined by HPLC analysis after conversion to the corresponding $N, N$-dibenzylamines. Thus, the resulting cycloalkenylamines were dissolved in $1.25 \mathrm{~mL}$ of $\mathrm{CH}_{2} \mathrm{Cl}_{2}-\mathrm{MeOH}-\mathrm{H}_{2} \mathrm{O}$ (1:1:0.5). To the solution was added $\mathrm{K}_{2} \mathrm{CO}_{3}(69 \mathrm{mg}$, $0.5 \mathrm{mmol}$ ), and benzyl bromide $(51 \mathrm{mg}, 0.3 \mathrm{mmol})$. The reaction mixture was stirred for $1 \mathrm{hr}$ and extracted with ethyl acetate and dried over $\mathrm{Na}_{2} \mathrm{SO}_{4}$ and concentrated in vacuo. The resulting residue was chromatographed on silica gel (eluent: ethyl acetate/hexane $=1 / 10-1 / 4$ ) to give $N, N$ dibenzylamines 7a, 8a, 9a, and 10a.

\title{
Chart I
}
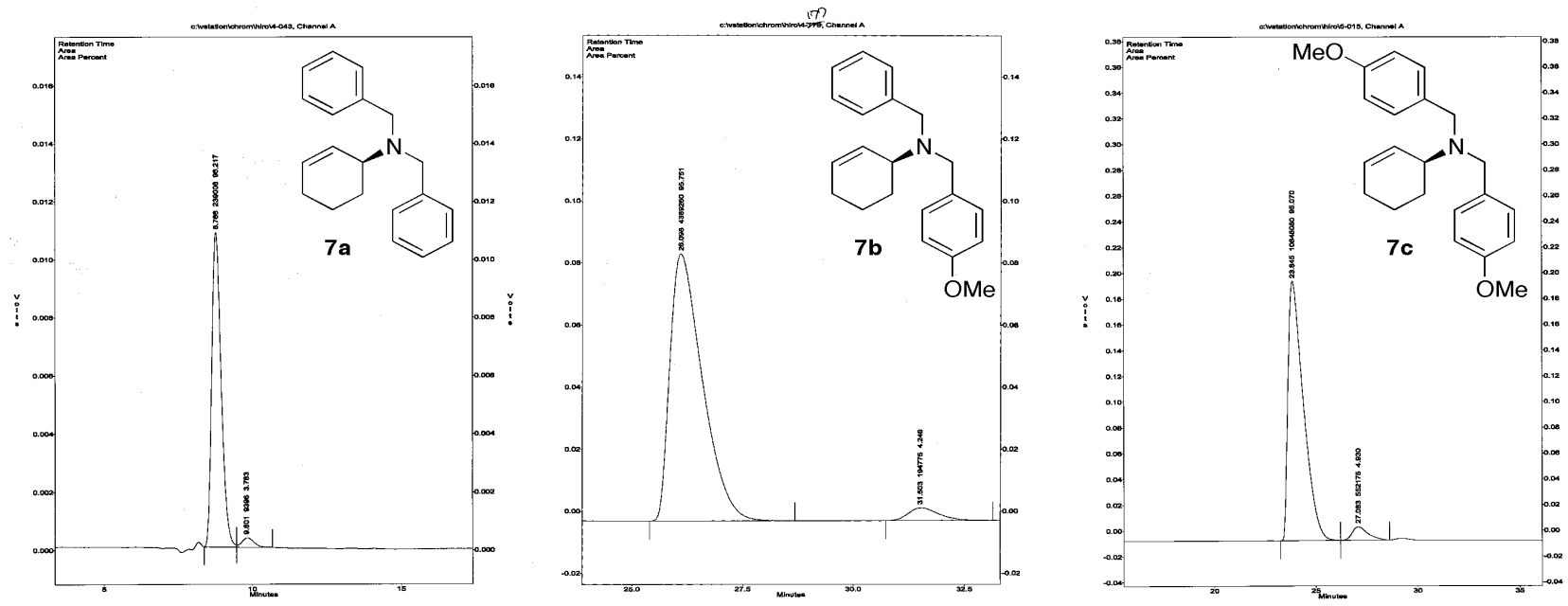


\section{Chart II}

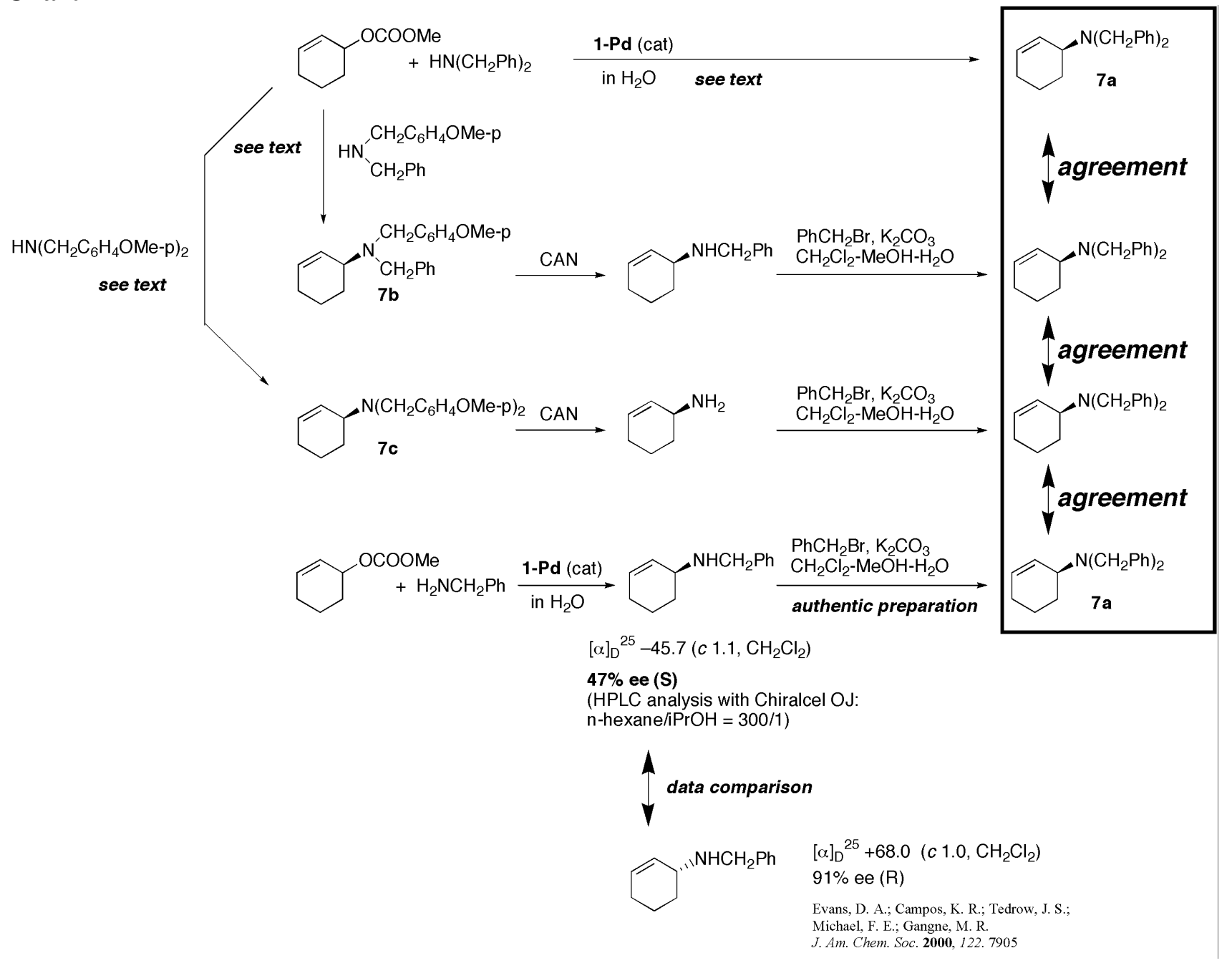

The absolute configuration of $7 \mathbf{a}$ was determined to be $S$ by comparison of its specific rotation with the authentic sample $((S)-7 \mathbf{a})$ prepared from (S)-benzyl(cyclohexen-2-yl)amine. (S)-Benzyl(cyclohexen-2-yl)amine was prepared by the asymmetric amination of rac-2 with benzylamine with 1-Pd under the standard asymmetric amination conditions. Its enantiomeric purity and absolute configuration were determined by chiral HPLC analysis and specific rotation measurement (see, ref. 8f: Evans, D. A.; Campos, K. R.; Tedrow, J. S.; Michael, F. E.; Gangne, M. R. J. Am. Chem. Soc. 2000, 122. 7905), respectively. (S)Benzyl(cyclohexen-2-yl)amine was readily converted to the authentic sample of $(S)$-7a by treatment with benzyl bromide (Chart II).

The absolute configuration of $\mathbf{7 b}$ and $\mathbf{7} \mathbf{c}$ were determined by chemical correlation to $\mathbf{7 a}$. Thus, $\mathbf{7 b}$ and $\mathbf{7} \mathbf{c}$ underwent the oxidative cleavage of their N-methoxybenzyl groups by use of CAN to give benzyl(cyclohexen2-yl)amine and cyclohexenylamine, respectively. The resulting amines were treated with benzyl bromide to give 7a. The specific rotations of both dibenzylamines, $\mathbf{7 a}$ from $\mathbf{7 b}$ and that from $\mathbf{7 c}$, revealed that the absolute configuration of the starting $\mathbf{7 b}$ and $\mathbf{7} \mathbf{c}$ prepared by the asymmetric amination were both $S$. Enantiomeric purities of $(S)-7 \mathbf{a}$ obtained from $\mathbf{7 b}$ and $\mathbf{7 c}$ were determined by HPLC analysis to be $92 \%$ ee and $91 \%$ ee, respectively, to demonstrate perfect stereochemical integrity of CAN oxidation step.

$(\boldsymbol{S})-\boldsymbol{N}, \boldsymbol{N}$-Dibenzyl(cyclohepten-2-yl)amine $8 \mathrm{a}: \quad 91 \%$ yield; $[\alpha]_{\mathrm{D}}{ }^{25}$ +15.7 ( $c$ 1.4, dichloromethane); ${ }^{1} \mathrm{H}$ NMR (chloroform- $d$ ) $\delta 1.24-1.64(\mathrm{~m}$, 4H), 1.92 (br s, 2H), 2.01 (d, $J=12.2 \mathrm{~Hz}, 1 \mathrm{H}), 2.14(\mathrm{~m}, 1 \mathrm{H}), 3.32(\mathrm{~d}, J=$ $10.5 \mathrm{~Hz}, 1 \mathrm{H}), 3.55(\mathrm{~d}, J=13.9 \mathrm{~Hz}, 2 \mathrm{H}), 3.70(\mathrm{~d}, J=13.9 \mathrm{~Hz}, 2 \mathrm{H}), 5.80$ $(\mathrm{m}, 1 \mathrm{H}), 5.92(\mathrm{~d}, J=11.7 \mathrm{~Hz}, 1 \mathrm{H}), 7.20(\mathrm{t}, J=7.2 \mathrm{~Hz}, 2 \mathrm{H}), 7.28(\mathrm{t}, J=$ $7.4 \mathrm{~Hz}, 4 \mathrm{H}), 7.38(\mathrm{~d}, J=7.6 \mathrm{~Hz}, 4 \mathrm{H}) .{ }^{13} \mathrm{C}$ NMR (chloroform- $d$ ) $\delta 26.9$,
$28.5,28.6,28.7,54.0,59.0,126.5,128.0,128.4,131.0,136.0,140.5$. Anal Calcd for $\mathrm{C}_{21} \mathrm{H}_{25} \mathrm{~N}$ : C, 86.54; H, 8.65; N, 4.81. Found: C, 86.48; H, $8.70 ; \mathrm{N}, 4.80$. The enantiomeric excess was determined by HPLC analysis using a chiral stationary phase column (DAICEL OJ: eluent, n-hexane/2propanol=300/1; flow rate $0.5 \mathrm{~mL} / \mathrm{min}$ ) to be $98 \%$ ee. A typical HPLC chart is shown in Chart III. The absolute configuration was determined by HPLC analysis compared with the authentic $(S)$-8a, prepared from $(S)$ $N$-benzyl(cyclohepten-2-yl)amine which was obtained by the asymmetric amination of rac-3 with benzylamine.

(S)- $N$-Benzyl- $N$ - $p$-methoxybenzyl(cyclohepten-2-yl)amine $\quad 8 b$ : $82 \%$ yield; $[\alpha]_{\mathrm{D}}{ }^{25}+15.1$ (c 1.1 , dichloromethane); ${ }^{1} \mathrm{H}$ NMR (chloroformd) $\delta 1.24-1.74(\mathrm{~m}, 3 \mathrm{H}), 1.63(\mathrm{~m}, 1 \mathrm{H}), 1.94(\mathrm{~m}, 3 \mathrm{H}), 2.13(\mathrm{~m}, 1 \mathrm{H}), 3.31(\mathrm{br}$ $\mathrm{d}, J=10.0 \mathrm{~Hz}, 1 \mathrm{H}), 3.48(\mathrm{~d}, J=13.9 \mathrm{~Hz}, 1 \mathrm{H}), 3.53(\mathrm{~d}, J=14.2 \mathrm{~Hz}, 1 \mathrm{H})$, $3.62(\mathrm{~d}, J=13.7 \mathrm{~Hz}, 1 \mathrm{H}), 3.68(\mathrm{~d}, J=14.2 \mathrm{~Hz}, 1 \mathrm{H}), 3.76(\mathrm{~s}, 3 \mathrm{H}), 5.78(\mathrm{~m}$, $1 \mathrm{H}), 5.91(\mathrm{~d}, J=11.5 \mathrm{~Hz}, 1 \mathrm{H}), 6.82(\mathrm{~d}, J=8.5 \mathrm{~Hz}, 2 \mathrm{H}), 7,19(\mathrm{t}, J=7,4$ $\mathrm{Hz}, 1 \mathrm{H}), 7.27(\mathrm{~d}, J=8.5 \mathrm{~Hz}, 2 \mathrm{H}), 7.28(\mathrm{t}, J=6.8 \mathrm{~Hz}, 2 \mathrm{H}), 7.37(\mathrm{~d}, J=7.3$ $\mathrm{Hz}, 2 \mathrm{H}) . \quad{ }^{13} \mathrm{C}$ NMR (chloroform- $d$ ) $\delta 26.9,28.5,28.6,28.7,53.3,53.8$, 55.2, 58.8, 113.4, 126.5, 128.0, 128.4, 129.5, 130.9, 132.5, 136.1, 140.7, 158.3. Anal Calcd for $\mathrm{C}_{22} \mathrm{H}_{27} \mathrm{NO}: \mathrm{C}, 82.19 ; \mathrm{H}, 8.47 ; \mathrm{N}, 4.36$. Found: $\mathrm{C}$, $81.87 ; \mathrm{H}, 8.50 ; \mathrm{N}, 4.26$. The enantiomeric excess was determined by HPLC analysis using a chiral stationary phase column (DAICEL OD-H: eluent, n-hexane/2-propanol=1000/1; flow rate $0.5 \mathrm{~mL} / \mathrm{min}$ ) to be $97 \%$ ee. A typical HPLC chart is shown in Chart III. The absolute configuration was determined by chemical correlation to $\mathbf{8 a}$.

(S)- $\boldsymbol{N}, \boldsymbol{N}$-Bis-p-methoxybenzyl(cyclohepten-2-yl)amine $\quad 8 c: \quad 89 \%$ yield; $[\alpha]_{\mathrm{D}}{ }^{25}+11.7$ (c 1.9, dichloromethane); ${ }^{1} \mathrm{H}$ NMR (chloroform- $d$ ) $\delta$ $1.23-1.49$ (m, 3H), $1.63(\mathrm{~m}, 1 \mathrm{H}), 1.94(\mathrm{~m}, 3 \mathrm{H}), 2.13(\mathrm{~m}, 1 \mathrm{H}), 3.29$ (br d, $J$ 


\section{Chart III}
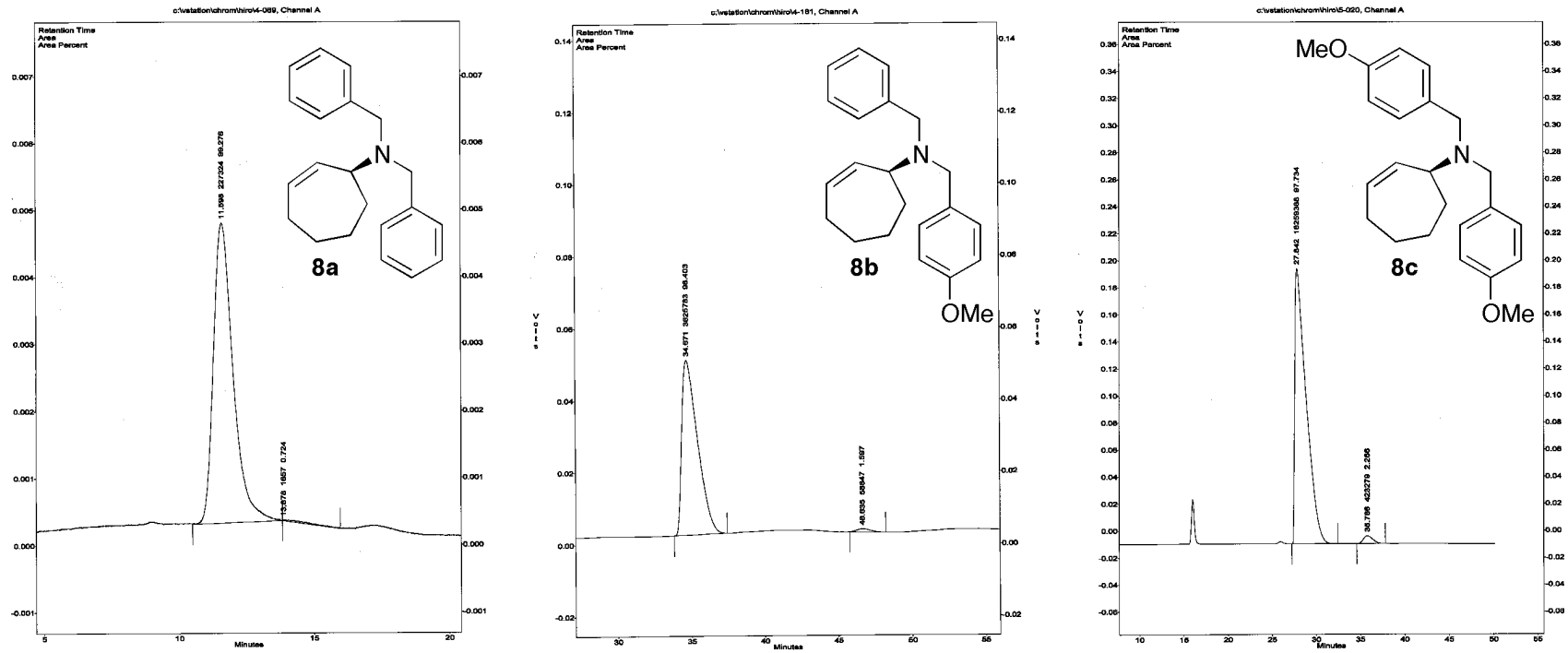

$=10.0 \mathrm{~Hz}, 1 \mathrm{H}), 3.46(\mathrm{~d}, J=13.7 \mathrm{~Hz}, 2 \mathrm{H}), 3.61(\mathrm{~d}, J=13.7 \mathrm{~Hz}, 2 \mathrm{H}), 3.78$ $(\mathrm{s}, 6 \mathrm{H}), 5.78(\mathrm{~m}, 1 \mathrm{H}), 5.89(\mathrm{br} \mathrm{d}, J=11.7 \mathrm{~Hz}, 1 \mathrm{H}), 6.83(\mathrm{~d}, J=8.5 \mathrm{~Hz}$, $4 \mathrm{H}), 7.27(\mathrm{~d}, J=8.3 \mathrm{~Hz}, 4 \mathrm{H}) .{ }^{13} \mathrm{C}$ NMR (chloroform- $d$ ) $\delta 26.9,28.5$, 28.6, 28.7, 53.1, 55.2, 58.6, 113.5, 129.5, 130.8, 132.6, 136.2, 158.3. Anal Calcd for $\mathrm{C}_{23} \mathrm{H}_{29} \mathrm{NO}_{2}$ : C, 78.58; H, 8.32; N, 3.99. Found: C, 78.53; $\mathrm{H}, 8.65 ; \mathrm{N}, 3.99$. The enantiomeric excess was determined by HPLC analysis using a chiral stationary phase column (DAICEL OD-H: eluent, n-hexane/2-propanol=1000/1; flow rate $0.5 \mathrm{~mL} / \mathrm{min}$ ) to be $96 \%$ ee. A typical HPLC chart is shown in Chart III. The absolute configuration was determined by chemical correlation to $\mathbf{8 a}$.

The absolute configuration of $\mathbf{8 a}$ was determined to be $S$ by chemical correlation similar to the method shown in Chart II. Thus, the authentic $(S)$-8a was prepared from $(S)$-benzyl(cyclohepten-2-yl)amine which was obtained by the asymmetric amination of rac-3 with benzylamine with 1Pd under the standard asymmetric amination conditions. Enantiomeric purity and absolute configuration of $(S)$-benzyl(cyclohepten-2-yl)amine were determined by chiral HPLC analysis and specific rotation measurement (see, ref. 8f: Evans, D. A.; Campos, K. R.; Tedrow, J. S.; Michael, F. E.; Gangne, M. R. J. Am. Chem. Soc. 2000, 122. 7905), respectively. (S)-Benzyl(cyclohepten-2-yl)amine was readily converted to the authentic sample of $(S)$-8a by treatment with benzyl bromide.

The absolute configuration of $\mathbf{8 b}$ and $\mathbf{8 c}$ were determined by chemical correlation to $\mathbf{8 a}$. Thus, $\mathbf{8 b}$ and $\mathbf{8 c}$ underwent the oxidative cleavage of their N-methoxybenzyl groups by use of CAN to give benzyl(cyclohepten-2-yl)amine and cycloheptenylamine, respectively. The resulting amines were treated with benzyl bromide to give $\mathbf{8 a}$. The specific rotations of both dibenzylamines, $\mathbf{8 a}$ from $\mathbf{8 b}$ and that from $\mathbf{8 c}$, revealed that the absolute configuration of the starting $\mathbf{8 b}$ and $\mathbf{8 c}$ prepared by the asymmetric amination were both $S$. Enantiomeric purities of $(S)$ 8a obtained from $\mathbf{8 b}$ and $\mathbf{8 c}$ were determined by HPLC analysis to be $97 \%$ ee and $95 \%$ ee, respectively, to demonstrate perfect stereochemical integrity of CAN oxidation step.

(1S,5S)- $N, N$-Dibenzyl(5-methoxycarbonylcyclohexen-2-yl)amine 9a: $61 \%$ yield; $[\alpha]_{\mathrm{D}}{ }^{25}+39.4$ (c 1.4 , dichloromethane); ${ }^{1} \mathrm{H}$ NMR (chloroform- $d$ ) $\delta 1.66(\mathrm{dd}, J=12.5,23.7 \mathrm{~Hz}, 1 \mathrm{H}), 2.22(\mathrm{~m}, 3 \mathrm{H}), 2.52(\mathrm{~m}$, $1 \mathrm{H}), 3.45(\mathrm{~m}, 1 \mathrm{H}), 3.55(\mathrm{~d}, J=14.2 \mathrm{~Hz}, 2 \mathrm{H}), 3.69(\mathrm{~s}, 3 \mathrm{H}), 3.71(\mathrm{~d}, \mathrm{~J}=$ $14.2 \mathrm{~Hz}, 2 \mathrm{H}), 5.78(\mathrm{~m}, 2 \mathrm{H}), 7.20(\mathrm{t}, J=7.1 \mathrm{~Hz}, 2 \mathrm{H}), 7.29(\mathrm{t}, \mathrm{J}=7.3 \mathrm{~Hz}$, $4 \mathrm{H}), 7.38(\mathrm{~d}, \mathrm{~J}=7.3 \mathrm{~Hz}, 4 \mathrm{H}) .{ }^{13} \mathrm{C}$ NMR (chloroform- $d$ ) $\delta 25.9,28.1$, 39.4, 51.7, 53.7, 54.7, 126.7, 127.8, 128.1, 128.3, 130.7, 140.3, 175.7. Anal Calcd for $\mathrm{C}_{22} \mathrm{H}_{25} \mathrm{NO}_{2}$ : C, 78.76; $\mathrm{H}, 7.52 ; \mathrm{N}, 4.18$. Found: C, 78.53; $\mathrm{H}, 7.65 ; \mathrm{N}, 4.00$. The enantiomeric excess was determined by HPLC analysis using a chiral stationary phase column (DAICEL OD-H: eluent, n-hexane/2-propanol=100/1; flow rate $0.5 \mathrm{~mL} / \mathrm{min}$ ) to be $90 \%$ ee. A typical HPLC chart is shown in Chart IV. The absolute configuration of 9a was assigned to be $1 S, 5 S$ by the similarity of HPLC elution order and molecular modeling studies on asymmetric induction.

\section{(1S,5S)- $N$-Benzyl- $N$ - $p$-methoxybenzyl(5-methoxycarbonyl-} cyclohexen-2-yl)amine 9 b: $\quad 80 \%$ yield; $[\alpha]_{D}^{25}+40.0 \quad(c \quad 2.1$, dichloromethane); ${ }^{1} \mathrm{H}$ NMR (chloroform- $d$ ) $\delta 1.64(\mathrm{dd}, \mathrm{J}=12.5,23.7 \mathrm{~Hz}$, $1 \mathrm{H}), 2.22(\mathrm{br} \mathrm{s}, 3 \mathrm{H}), 2.52(\mathrm{~m}, 1 \mathrm{H}), 3.43(\mathrm{~m}, 1 \mathrm{H}), 3.48(\mathrm{~d}, J=13.9 \mathrm{~Hz}, 1 \mathrm{H})$, $3.52(\mathrm{~d}, J=14.2 \mathrm{~Hz}, 1 \mathrm{H}), 3.64(\mathrm{~d}, J=13.9 \mathrm{~Hz}, 1 \mathrm{H}), 3.69(\mathrm{~s}, 3 \mathrm{H}), 3.70(\mathrm{~d}$, $J=14.2 \mathrm{~Hz}, 1 \mathrm{H}), 3.78(\mathrm{~s}, 3 \mathrm{H}), 5.73-5.81(\mathrm{~m}, 2 \mathrm{H}), 6.83(\mathrm{~d}, J=8.5 \mathrm{~Hz}, 2 \mathrm{H})$, $7.20(\mathrm{t}, J=7.2 \mathrm{~Hz}, 1 \mathrm{H}), 7.28(\mathrm{~d}, J=8.5 \mathrm{~Hz}, 2 \mathrm{H}), 7.28(\mathrm{t}, J=7.1 \mathrm{~Hz}, 2 \mathrm{H})$, $7.37(\mathrm{~d}, J=7.3 \mathrm{~Hz}, 2 \mathrm{H}) .{ }^{13} \mathrm{C}$ NMR (chloroform- $d$ ) $\delta 25.9,28.1,39.4$, $51.7,53.0,53.5,54.5,55.2,113.5,126.6,127.6,128.1,128.3,129.4$, 130.8, 132.2, 140.4, 158.4, 175.7. Anal Calcd for $\mathrm{C}_{23} \mathrm{H}_{27} \mathrm{NO}_{3}$ : C, 75.58; H, 7.45; N, 3.83. Found: C, 75.23; H, 7.66; N, 4.11. The enantiomeric excess was determined by HPLC analysis using a chiral stationary phase column (DAICEL OD-H: eluent, n-hexane/2-propanol=98/2; flow rate 0.5 $\mathrm{mL} / \mathrm{min}$ ) to be $96 \%$ ee. A typical HPLC chart is shown in Chart IV. The absolute configuration was assigned to be $1 S, 5 S$ determined by chemical correlation to 9a via CAN oxidation followed by benzylation.

$(1 S, 5 S)$ - $N, N$-Bis- $p$-methoxybenzyl(5-methoxycarbonylcyclohexen2-yl)amine 9c: $\quad 85 \%$ yield; $[\alpha]_{\mathrm{D}}{ }^{25}+38.5$ (c 1.1, dichloromethane); ${ }^{1} \mathrm{H}$ NMR (chloroform- $d$ ) $\delta 1.60(\mathrm{dd}, \mathrm{J}=12.2,23.9 \mathrm{~Hz}, 1 \mathrm{H}), 2.19(\mathrm{~m}, 3 \mathrm{H})$, $2.52(\mathrm{~m}, 1 \mathrm{H}), 3.43(\mathrm{br} \mathrm{s}, 1 \mathrm{H}), 3.46(\mathrm{~d}, \mathrm{~J}=13.9 \mathrm{~Hz}, 2 \mathrm{H}), 3.62(\mathrm{~d}, \mathrm{~J}=13.9$ $\mathrm{Hz}, 2 \mathrm{H}), 3.69(\mathrm{~s}, 3 \mathrm{H}), 3.78(\mathrm{~s}, 6 \mathrm{H}), 5.73(\mathrm{~d}, \mathrm{~J}=10.2 \mathrm{~Hz}, 1 \mathrm{H}), 5.78(\mathrm{~d}, \mathrm{~J}=$ $10.2 \mathrm{~Hz}, 1 \mathrm{H}), 6.83(\mathrm{~d}, \mathrm{~J}=8.5 \mathrm{~Hz}, 4 \mathrm{H}), 7.27(\mathrm{~d}, \mathrm{~J}=8.5 \mathrm{~Hz}, 4 \mathrm{H}) .{ }^{13} \mathrm{C}$ NMR (chloroform- $d$ ) $\delta 25.9,28.1,39.4,51.7,52.9,54.4,55.2,113.5$, 127.5, 129.4, 130.9, 132.3, 158.4, 175.7. Anal Calcd for $\mathrm{C}_{24} \mathrm{H}_{29} \mathrm{NO}_{4}$ : C, 72.87; H, 7.40; N, 3.54. Found: C, 72.75; H, 7.56; N, 3.38. The enantiomeric excess was determined by HPLC analysis using a chiral stationary phase column (DAICEL OD-H: eluent, n-hexane/2propanol=98/2; flow rate $0.5 \mathrm{~mL} / \mathrm{min}$ ) to be $95 \%$ ee. A typical HPLC chart is given in Chart IV. The absolute configuration was assigned to be $1 S, 5 S$ determined by chemical correlation to 9a via CAN oxidation followed by benzylation.

tert-Butyl (5R)-5-dibenzylamino-1,2,5,6-tetrahydropyridinecarboxylate 10a: $76 \%$ yield; $[\alpha]_{D}{ }^{25}-21.4$ (c 0.91 , dichloromethane); ${ }^{1} \mathrm{H}$ NMR (chloroform- $d$ ) $\delta 1.48(\mathrm{~s}, 9 \mathrm{H}), 3.35(\mathrm{br} \mathrm{s}, 1 \mathrm{H}), 3.57(\mathrm{~d}, J=14.2 \mathrm{~Hz}$, $2 \mathrm{H}), 3.82$ (d, $J=14.2 \mathrm{~Hz}, 2 \mathrm{H}), 3.45-3.90$ (br m, 4H), 5.84 (br s, $2 \mathrm{H}), 7.22$ $(\mathrm{t}, J=6.8 \mathrm{~Hz}, 2 \mathrm{H}), 7.29(\mathrm{t}, J=7.1 \mathrm{~Hz}, 4 \mathrm{H}), 7.36(\mathrm{~d}, J=7.1 \mathrm{~Hz}, 4 \mathrm{H}) .{ }^{13} \mathrm{C}$ NMR (chloroform- $d$ ) $\delta 28.6,39.8,41.7,42.9,43.5,52.2,53.8,54.0,79.7$, $126.7,127.3,127.9,128.1,128.3,128.4,128.6,140.1,154.4 . \quad$ Anal Calcd for $\mathrm{C}_{24} \mathrm{H}_{30} \mathrm{~N}_{2} \mathrm{O}_{2}: \mathrm{C}, 76.14 ; \mathrm{H}, 7.99 ; \mathrm{N}, 7.40$. Found: $\mathrm{C}, 75.95 ; \mathrm{H}$, 7.98; N, 7.21. The enantiomeric excess was determined by HPLC analysis using a chiral stationary phase column (DAICEL OD-H: eluent, n-hexane $/ 2$-propanol=9/1; flow rate $0.5 \mathrm{~mL} / \mathrm{min}$ ) to be $95 \%$ ee. A 
typical HPLC chart is given in Chart V. The absolute configuration was determined by HPLC analysis compared with the authentic $(R)-\mathbf{1 0 a}$.

tert-Butyl $\quad(5 R)-5-N$-benzyl- $N$ - $p$-mothoxybenzylamino-1,2,5,6-tetrahydropyridinecarboxylate 10b: $99 \%$ yield; $[\alpha]_{\mathrm{D}}^{25}-21.5$ (c 1.4 , dichloromethane); ${ }^{1} \mathrm{H}$ NMR (chloroform- $d$ ) $\delta 1.48$ (s, 9H), 3.34 (br s, 1H), $3.50(\mathrm{~d}, J=14.2 \mathrm{~Hz}, 1 \mathrm{H}), 3.54(\mathrm{~d}, J=13.9 \mathrm{~Hz}, 1 \mathrm{H}), 3.75(\mathrm{~d}, J=13.9 \mathrm{~Hz}$, $1 \mathrm{H}), 3.78$ (s, 3H), 3.81 (d, $J=14.2 \mathrm{~Hz}, 1 \mathrm{H}), 3.49-3.87$ (br m, 4H), 5.83 (br $\mathrm{s}, 2 \mathrm{H}), 6.83(\mathrm{~d}, J=8.5 \mathrm{~Hz}, 2 \mathrm{H}), 7.21(\mathrm{t}, J=7.1 \mathrm{~Hz}, 1 \mathrm{H}), 7.27(\mathrm{~d}, J=8.5$ $\mathrm{Hz}, 2 \mathrm{H}), 7.29(\mathrm{t}, J=7.3 \mathrm{~Hz}, 2 \mathrm{H}), 7.36(\mathrm{~d}, J=7.3 \mathrm{~Hz}, 2 \mathrm{H}) .{ }^{13} \mathrm{C} \mathrm{NMR}$ (chloroform- $d$ ) $\delta 28.6,39.8,41.7,43.0,43.5,52.0,53.1,53.3,53.6,53.8$, 55.3, 79.7, 113.6, 126.5, 126.7, 127.1, 128.1, 128.4, 129.5, 132.0, 140.3, 154.4, 158.4. Anal Calcd for $\mathrm{C}_{25} \mathrm{H}_{32} \mathrm{~N}_{2} \mathrm{O}_{3}: \mathrm{C}, 73.49 ; \mathrm{H}, 7.90 ; \mathrm{N}, 6.86$ Found: C, 73.16; H, 7.78; N, 6.58. The enantiomeric excess was determined by HPLC analysis using a chiral stationary phase column (DAICEL AD: eluent, n-hexane/2-propanol=9/1; flow rate $0.5 \mathrm{~mL} / \mathrm{min}$ ) to be $93 \%$ ee. The absolute configuration was determined by comparison of the specific rotation value with the authentic $\mathbf{1 0 b}$ prepared from $(S)$ 10a.

tert-Butyl (5R)-5-Bis( $p$-methoxybenzyl)amino-1,2,5,6-tetrahydropyridinecarboxylate 10c: $59 \%$ yield; $[\mathrm{a}]_{\mathrm{D}}^{25}-21.0 \quad$ (c 0.60 dichloromethane); ${ }^{1} \mathrm{H}$ NMR (chloroform- $d$ ) d 1.48 (s, 9H), 3.33 (br s, 1H), $3.48(\mathrm{~d}, \mathrm{~J}=13.8 \mathrm{~Hz}, 2 \mathrm{H}), 3.73(\mathrm{~d}, \mathrm{~J}=13.8 \mathrm{~Hz}, 2 \mathrm{H}), 3.78(\mathrm{~s}, 6 \mathrm{H}), 3.45$ $3.90(\mathrm{~m}, 4 \mathrm{H}), 5.82$ (br s, 2H), 6.83 (d, J = 7.6 Hz, 4H), 7.26 (d, J = 7.8 Hz, $4 \mathrm{H}) . \quad{ }^{13} \mathrm{C}$ NMR (chloroform- $d$ ) $\delta 28.6,52.0,52.9,53.1,55.3,79.7,113.5$, $126.4,127.0,128.1,129.5,132.2,154.4,158.4$. The enantiomeric excess was determined by HPLC analysis using a chiral stationary phase column
(DAICEL AD: eluent, n-hexane/2-propanol=98/2; flow rate $0.5 \mathrm{~mL} / \mathrm{min}$ ) to be $94 \%$ ee. Anal Calcd for $\mathrm{C}_{26} \mathrm{H}_{34} \mathrm{~N}_{2} \mathrm{O}_{4}: \mathrm{C}, 71.19 ; \mathrm{H}, 7.82 ; \mathrm{N}, 6.39$. Found: $\mathrm{C}, 71.16 ; \mathrm{H}, 7.78 ; \mathrm{N}, 6.18$. The absolute configuration was determined by chemical correlation to $\mathbf{1 0 a}$.

The absolute configuration of $\mathbf{1 0 a}$ was determined to be $R$ by chemical correlation similar to the method shown in Chart II. Thus, the authentic $(R)-10 \mathrm{a}$ was prepared from $(R)$-N-benzyl-1,2,5,6-tetrahydropyridinecarboxylate which was obtained by the asymmetric amination of rac-5 with benzylamine in the presence of 1-Pd under the standard asymmetric amination conditions. Enantiomeric purity and absolute configuration of the resulting amine were determined by chiral HPLC analysis and specific rotation measurement (see, ref. 8f: Evans, D. A.; Campos, K. R.; Tedrow, J. S.; Michael, F. E.; Gangne, M. R. J. Am. Chem. Soc. 2000, 122. 7905), respectively. (R)-N-Benzyl-1,2,5,6-tetrahydropyridinecarboxylate was readily converted to the authentic sample of $(S)$-10a by treatment with benzyl bromide.

The absolute configuration of $\mathbf{1 0 b}$ and $\mathbf{1 0 c}$ were determined by chemical correlation to 10a. Thus, 10b and 10c underwent the oxidative cleavage of their N-methoxybenzyl groups by use of CAN to give secondary and primary amine, respectively. The resulting amines were treated with benzyl bromide to give 10a. The specific rotations of both dibenzylamines, 10a from $10 \mathbf{b}$ and that from 10c, revealed that the absolute configuration of the starting 10b and 10c prepared by the asymmetric amination were both $R$. Enantiomeric purities of $(S)-\mathbf{1 0 a}$ obtained from 10b and 10c were determined by HPLC analysis to be $93 \%$ ee and $94 \%$ ee, respectively, to demonstrate perfect stereochemical integrity of CAN oxidation step.

\section{Chart IV}
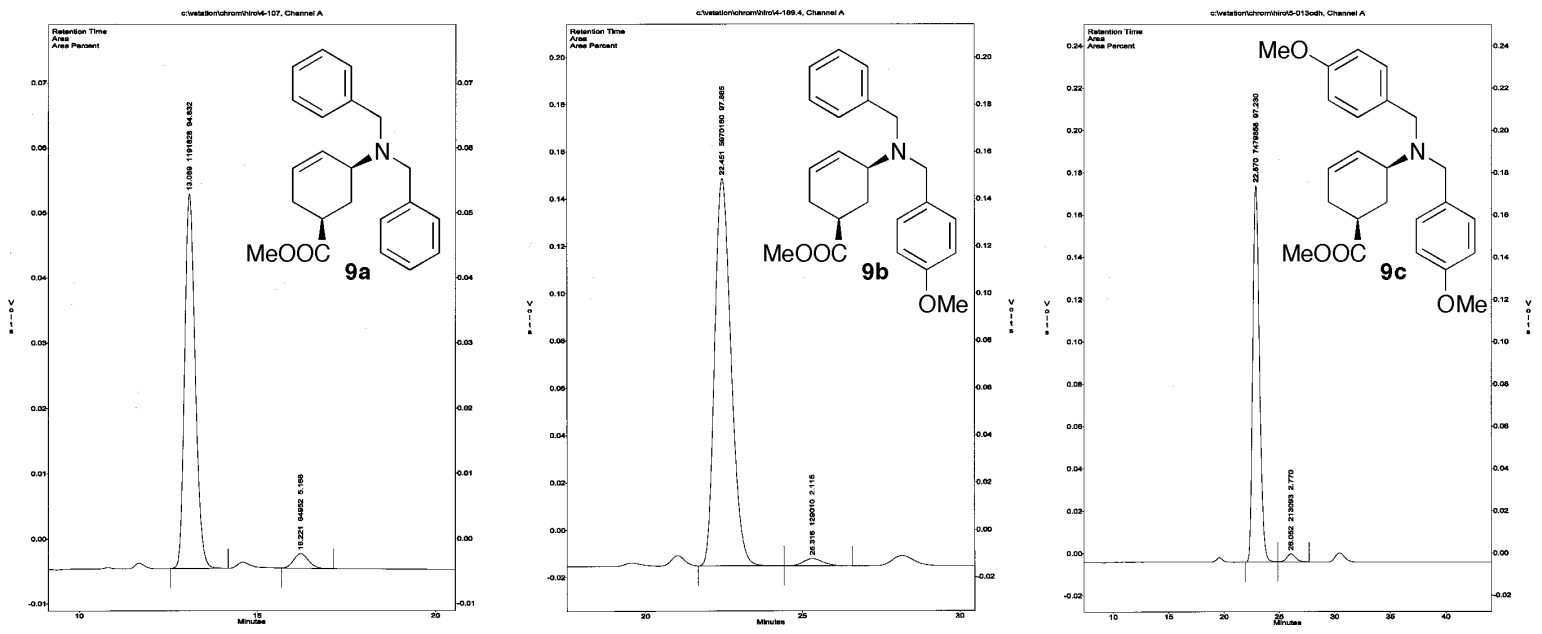

\section{Chart V}

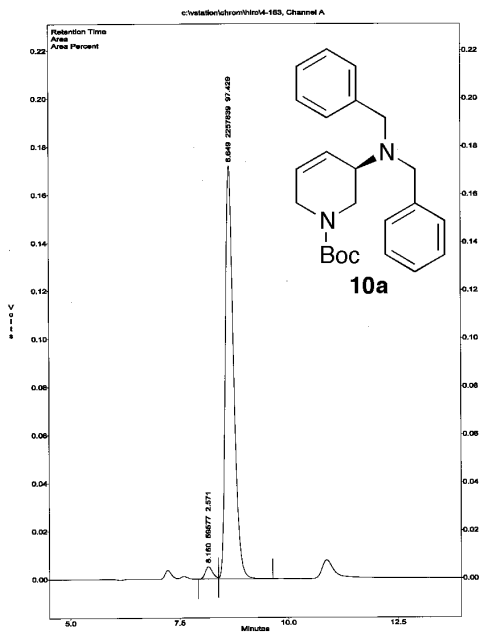

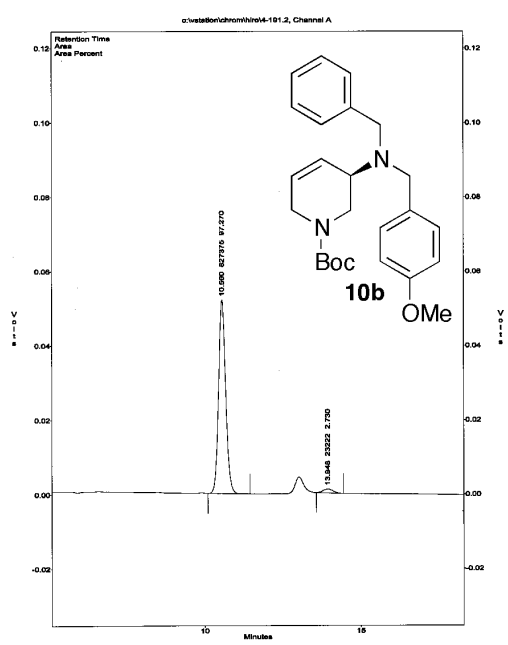

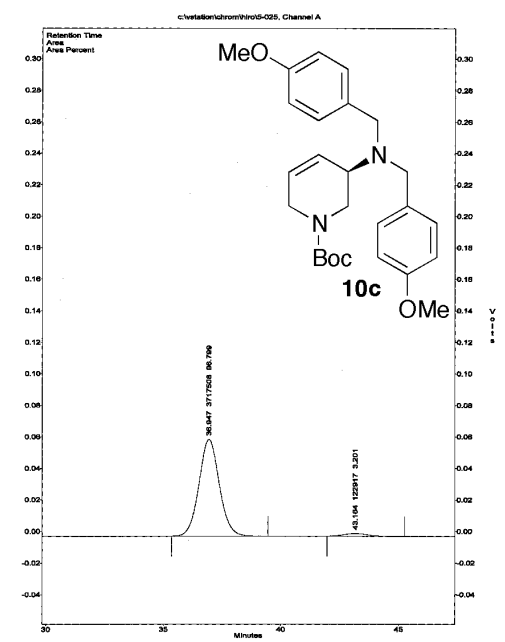

